\title{
Pendidikan Agama Islam Penangkal Radikalisme
}

\author{
Sri Mulya Nurhakiky ${ }^{1}$, Muhammad Naelul Mubarok ${ }^{2}$ \\ ${ }^{1}$ Fakultas Tarbiyah dan Keguruan UIN Sunan Gunung Djati, Bandung, Indonesia \\ ${ }^{2}$ Fakultas Tarbiyah Institut PTIQ Jakarta, Indonesia \\ ${ }^{1}$ nurhakiky14@gmail.com
}

\begin{abstract}
Abstrak:
Indonesia sebagai negara yang menganut paham bhinneka tunggal ika ternyata belum mampu menunjukkan ketangguhannya untuk meminimalisir sikap-sikap radikal dan ekstrim dari sebagian pemeluk agamanya. Pendangkalan terhadap agama dan fanatisme mengakibatkan rasa superioritas atas pemeluk agama lain. Radikalisme agama menyebabkan tindakan penuh kekerasan disebabkan pemaknaan yang parsial terhadap konsep jihad dalam Islam, konsekuensi logis dari interpretasi ini adalah penyandingan terorisme sebagai buah dari radikalisme. Ideologi radikal atau paham radikalisme telah berkembang demikian marak sehingga menembus batas-batas pendidikan formal dan nonfomal. Tulisan ini berusaha mengungkapkan bagaimana nilai luhur Pendidikan Agama Islam (PAI) dalam mencegah paham radikalisme Islam
\end{abstract}

Kata Kunci : Bhineka Tunggal Ika, PAI, Radikalisme

\begin{abstract}
:
Indonesia as a country that adheres to the understanding of a single bhinneka if it turns out it has not been able to demonstrate its resilience to minimize the radical and extreme attitudes of some of its religious adherents. Siltation of religion and fanaticism results in a sense of superiority over adherents of other religions. Religious radicalism causes violent actions caused by a partial interpretation of the concept of jihad in Islam, the logical consequence of this interpretation is the matching of terrorism as the fruit of radicalism. Radical ideology or understanding of radicalism has developed so rampant that it penetrates the boundaries of formal and non-formal education. This paper tries to reveal how the noble values of Islamic Religious Education (PAI) in preventing radical
\end{abstract}

Keywords: Bhineka Tunggal Ika, PAI, Radicalizm 


\section{Pendahuluan}

Masalah radikalisme dalam Islam yang masuk melalui lingkungan pendidikn fomal sepeti di sekolah mupun peguuan tinggi merupakan masalah yang sangat menarik jika dikaji karena masuknya paham tersebut sangat jarang diketahui oleh komponen-komponen pendidikan yang ada di sekolah. Sepeti kasus dugaan radikalisme yang menjerat salah seoang dosen berinisial $A B$ yang berasal dari IPB sebagai salah satu perguruan tinggi ternama di Indonesia pada September 2019. ${ }^{1}$ Berlanjut pula pada kasus penusukan terhadap Wiranto (Menko Polhukam pada waktu itu) oleh pasangan suami Istri yang diduga kelompok Islam radikal yang lantang menyuarakan pemerintah sebagai thaghut (berhala). Hal tersebut menunjukkan bahwa seluruh elemen masyarakat Indonesia rentan terhadap paham-paham ekstrim terutama yang menggunakan agama sebagai basis ideologinya.

Munculnya kasus-kasus kekerasan dan terorisme mengatasnamakan agama tersebut dilatarbelakangi oleh fenomena fanatisme keagamaan yang sempit sebagai dampak dari meluasnya gerakan radikalisme Islam. Zunly Nadia mengungkapkan bahwa radikalisme Islam dinisbatkan sebagai gerakan yang berpandangan kolot dan sering menggunakan kekerasan dalam mengajarkan serta mempertahankan keyakinan mereka. ${ }^{2}$

Dalam sejarah Indonesia pernah pula terjadi, seperti yang dilakukan oleh Kartosuwiryo yang awalnya adalah teman Soekarno dalam pergerakan perjuangan tetapi kemudian Kartosuwiryo memisahkan diri dari Soekarno karena beberapa alasan di antaranya perbedaan pendapat tentang hukum yang digunakan di Indonesia. Kemudian kelompok orang yang memiliki paham serupa, berusaha membentuk sebuah kelompok organisasi, seperti Hizbut Tahrir, Kesatuan Aksi Mahasiswa Muslim Indonesia (KAMMI), Ikhwanul Muslimin, Jamaah Islamiah dan lain-lain. Mereka adalah kelompok Islam yang kurang lunak terhadap kondisi kehidupan religiusitas di Indonesia yang ingin menjadikan syariat Islam sebagai hukum di Indonesia. Mereka mendakwahkan maksud dan tujuannya kepada masyarakat sekitar untuk mendukung keinginannya dalam mewujudkan pemerintahan Islam di Indonesia.

Salah satu pintu masuk paham atau pemikiran radikal ke Indonesia yaitu melalui aktifitas pendidikan dimana mayoritas pelajar Indonesia yang belajar di luar negeri, terutama dikawasan Timur Tengah. Yang amat disayangkan adalah pemahaman-pemahaman yang mereka dapatkan lantas ditelan bulat-bulat, dan memaksakan untuk diaplikasikan ke dalam

\footnotetext{
${ }^{1}$ Menjadi trending topik di berbagai situs berita harian online dan cetak

2 Zunly Nadia, Akar-akar Radikalisme Islam dalam Tafsir Fi Zilal al-Qur'an Karya Sayyid Quth,Mukaddimah, 18 (2), 2012: 301-323

102 | IQ (Ilmu Al-qur'an): Jurnal Pendidikan Islam | Volume 2 No. 012019
} 
sebuah sistem kehidupan masyarakat Indonesia yang amat berbeda dengan kehidupan di timur tengah tempet mereka belajar. Hal inilah yang menjadikan paham radikal menjadi sangat masif dan berkembang luas di Indonesia, khususnya pasca gerakan reformasi 1998 saat semua akses media telah bebas dari otoritas rezim pada waktu itu.

Dalam mendakwahkan maksud dan tujuannya mereka menawarkan ideologi-ideologi mereka dengan menggunakan cara kekerasan dan menampilkan aksi-aksi yang dapat merugikan banyak orang. Akan tetapi selain itu, mereka juga menggunakan cara yang halus bahkan hampir tidak kelihatan, yaitu dengan masuk ke dalam lembaga-lembaga pendidikan, baik lembaga formal maupun nonformal. kegagalan demi kegagalan menggunakan cara-cara yang cenderung keras menjadikan kelompok-kelompok ekstrim tersebut bermanufer masuk melalui jalur baru untuk mendapatkan pengikut yakni melalui media pendidikan formal, bulletin, media elektronik seperti radio televisi, buku-buku, teknologi Informasi internet dan saat ini merambah pada sector pendidikan formal yang cenderung eksklusif dan tertutup.

Pendidikan Islam adalah sebagian dari institusi yang ikut menjadi sorotan tatkala kerusuhan antar agama dan etnis muncul di beberapa tempat di Indonesia. Dengan tragedi tersebut, pendidikan dirasa perlu lebih ekstra memberikan bekal yang cukup terhadap peserta didik tentang bagaimana mereka mengembangkan sikap toleran terhadap perbedaandan keragaman yang ada di masyarakat. Oleh karena itu, penyadaran akan urgensi pluralisme dan desain pendidikan inklusif (terbuka) diharapkan mampu memerankan fungsi edukasi yang mampu membentuk insan ramah dan berempati kepada kegelisahan setiap insan tanpa terkecuali, termasuk mereka yang nonmuslim. ${ }^{3}$ Lalu pemahaman nilai-nilai PAI seperti apakah yang seharusnya diperkuat dalam upaya menangkal arus rdikalisme?

\section{Pendidikan Agama Islam}

Menurut Drs. Ahmad D. Marimba, Pendidikan islam adalah bimbingan jasmani, rohani berdasarkan hukum-hukum agama islam menuju kepada terbentuknya kepribadian utama menurut ukuran-ukuran Islam.

Musthafa Al-Ghulayaini mengemukakan bahwa Pendidikan Islam ialah menanamkan akhlak yang mulia di dalam jiwa anak dalam masa pertumbuhannya dan menyiraminya dengan air petunjuk dan nasihat, sehingga akhlak itu menjadi salah satu kemampuan (meresap dalam) jiwanya kemudian buahnya berwujud keutamaan, kebaikan dan cinta bekerja untuk kemanfaatan tanah air.

${ }^{3}$ Moh. Roqib, Filsafat Islam, 179. 
Zakiah Daradjat mendefinisikan Pendidikan Agama Islam sebagai suatu usaha untuk membina dan mengasuh peserta didik agar senantiasa dapat memahami ajaran Islam secara menyeluruh, lalu menghayati tujuan, yang pada akhirnya dapat mengamalkan serta menjadikan Islam sebagai pandangan hidup (Daradjat 2011, 86).

Dari pemaparan para ahli tersebut maka dapat kita katakana bahwa pada hakikatnya pendidikan Islam adalah suatu proses jangka panjang dalam membentuk seluruh elemen kemanusiaan yakni jasmani dan rohani peserta didik agar mencapai kebermaknaan dalam menjalani hidupnya sebagai manusia dengan meletakkan nilai-nilai luhur ajaran Islam sebagai pijakan hidupnya. Kebermaknaann hidup adalah muara dari pendidikan, baik kebermaknaan untuk individu maupun kebermakanaann yang bisa diberikan kepada lingkungan tempat hidupnya.

Di dalam GBPP PAI di sekolah umum, di jelaskan bahwa Pendidikan Agama Islam adalah usaha yang dilakukan secara sadar untuk menyiapkan siswa dalam meyakini, memahami, menghayati, dan mengamalkan agama Islam melalui kegiatan bimbingan, pengajaran, atau latihan dengan memerhatikan tuntutan untuk menghormati agama lain dalam hubungan kerukunan antar umat beragama dalam masyarakat untuk mewujudkan persatuan nasional (Muhaimain 2008, 75-76).

Dari pengertian diatas dapat di simpulkan bahwa Pendidikan Agama Islam adalah upaya sadar dan terencana untuk menyiapkan siswa guna memahami ajaran Islam secara menyeluruh dengan cara membina, mengasuh dan mengajar sebagai aktivitas asasi dan sebagai profesi dalam masyarakat.

Profil atau produk dari pendidikan adalah sosok atauprofil manusia yang utuh, komprehensif, dan sempurna, baik dariaspek jasmaniah maupun rohaniah, baik dari aspek keterampilan intelektual maupun keterampilan moral dan motorik, mulai dari cara bicara sampai cara menjalankan tugas atau aktivitas. Pendidikan benar-benar mengajarkan dan membimbing manusia untuk lebih memahami realitas serta mampu menghadapi problem hidup dan kehidupan. Kesalahan dalam praktik pendidikan akan berakibat fatal bagi kelangsungan kehidupan bangsa. Konsekuensinya, proses pendidikan tidak boleh dikotori dengan sikap dan perilaku yang bertolak belakang dengan visidan misi pendidikan yang sebenarnya. Semua elemen dalam proses pendidikan harus saling mendukung dan bersinergi 
secarapositif sehingga akan melahirkan kualitas proses dan produk pendidikan sesuai yang dicita-citakan. ${ }^{4}$

\section{Pengertian Radikalisme}

Menurut Kamus Besar Bahasa Indonesia (KBBI), radikalisme berarti (1) paham atau aliran yang radikal dalam politik; (2) paham atau aliran yang menginginkan perubahan atau pembaharuan sosial dan politik dengan cara kekerasan atau drastis; (3) sikap ekstrem dalam aliran politik (Bahasa 2008, 1130). Radikalisme tidak bisa dilabelkan hanya kepada Islam, karena radikalisme bisa menjangkit pada sector apapun dalam kehidupa manusia baik ekonomi, politik, problem sosial dan lain sebagainya tak terkecuali agama.

Namun dikarenakan maraknya aksi-aksi radikalisme yang terjadi dalam beberapa kurun waktu ini lebih cenderung ke dalam isu-isu ideologi keagamaan, maka seolah-olah agama adalah sarang radikalisme. Oleh karena itu menjadi benar tindakan yang dilakukan leh pemerintah dan aparat untuk memberikan edukasi tentang hakikat radikalisme dalam konteks yang lebih luas. Hal tersebut diperlukan guna menghindari stigma negatif terhadap suatu agama akan radikalisme yang sebenarnya hanya diperagakan oleh sebagian oknum ummat yang tidak bertanggung jawab dalam menjaga kestabilan kehidupan berbangsa dan bernegara.

Pada 17 Juli 2016 lalu pemimpin kelompok teroris Mujahidin Indonesia Timur, Santoso alias AbuWardah tewas dalam operasi yang dilakukan oleh TNI, ${ }^{5}$ banyak pihak menilai hal itu sebagi keberhasilan ikhtiar Negara menumpas akar-akar terorisme. Namun mungkinkah peristiwa tertembaknya seseorang dapat menjelaskan bahwa gerakan radikalisme di Indonesia telah berakhir?

Radikalisme dalam agama ibarat pisau bermata dua, di satu sisi, makna positif dari radikalisme adalah spirit menuju perubahan ke arah lebih baik yang lazim disebut ishlah (perbaikan) atau tajdid (pembaharuan). Dengan begitu radikalisme tidaklah bisa disamakan dengan ektrimitas atau kekerasan, ia akan sangat bermakna apabila dijalankan melalui pemahaman agama yang menyeluruh dan diaplikasikan untuk ranah pribadi. Namun di sisi lain, radikalisme akan menjadi berbahaya jika sampai pada tataran ghuluw (melampaui batas)

${ }^{4}$ M. Ngalim Purwanto, Ilmu Pendidikan Teoritis dan Praktis (Bandung: Remaja Rosdakarya,1995), hlm. 15.

5 Trending topik di berbagai situs berita online dan cetak 
dan ifrath (keterlaluan) ketika dipaksakan pada pemeluk baik internal agama maupun agama lain. ${ }^{6}$

Seorang tokoh agama terkemuka, KH. Hasyim Muzadi, yang ditemui ketika mengisi seminar nasional tentang deradikalisasi agama melalui peran mubalig di Jawa Tengah, mengatakan bahwa seseorang boleh saja berpikir secara radikal (berpikir secara mendalam sampai ke akar-akarnya) dan memang seharusnya seseorang seharusnya berpikir secara radikal (Rokhmad 2012,4). Akan tetapi hasil pemikiran tersebut akan berbahaya jika sudah menjadi isme yaitu mazhab atau ideologi, karena jika sudah menjadi mazhab seseorang tersebut akan keras dalam memaksakan hasil pemikirannya terhadap orang lain atau kelompok lain. Menurut Rokhmad, inilah yang disebut dengan radikalisme (Rokhmad 2012, $4)$.

Fenomena radikalisme Islam yang sering terjadi di beberapa negara, terutama negara Timur Tengah bukanlah fenomena yang baru dalam sejarah Islam. Banyak sekali faktor yang melatarbelakangi munculnya fenomena tersebut, di antaranya adalah faktor budaya, teologi, sosial ekonomi dan politik. Di Indonesia juga terjadi hal yang demikian meskipun kita tidak boleh menyamakan antara kaum Khawarij dengan sekelompok orang yang mengadakan pemberontakan terhadap suatu sistem yang memang sudah ditetapkan oleh pemerintah yang sah karena mereka mempunyai latar belakang yang bisa dikatakan berbeda. ${ }^{7}$

Radikalisme sebagai fenomena internasional akan menjadi kuat dan berbahaya bagi stabilitas keamanan dunia manakala mereka yang beragama justru memiliki peran besar di dalamnya. Hal itu dikarenakan kaum radikalis yang beragama akan cepat memperoleh fatwafatwa fiqhiyyah bagi perilakunya yang menjadikan dirinya merasa puas dengan fatwa-fatwa tersebut, seperti fikrah at-takfir (ide pengkafiran), merampas hak milik orang lain, menyandera wanita dan anak-anak, hingga membunuh mereka yang dianggap kafir. Itulah sebabnya mengapa radikalisme agama dikatakan oleh banyak kalangan sebagai benih munculnya terorisme. ${ }^{8}$

Teori-Teori Tentang Radikalisme Islam

Untuk memberikan istilah terhadap gerakan Islam, yang menolak tatanan sosial yang sudah ada dan berusaha menerapkan suatu model tatanan tersendiri yang berbasiskan nilai-

${ }^{6}$ Emna Laisa, Islam dan Radikalisme (Islamuna Volume 1 Nomor 1 Juni 2014), hlm.2.

7 Arif Mulyadi,Peran guru agama Islam dalam Menanggulangi Paham Radikalisme, (Safira Vol 2/No.1/2017) hal.50

8 Novan Ardy Wiyani, Pendidikan Agama Islam Berbasis Anti Terorisme Di SMA,(Jurnal Pendidikan Islam :Volume II, Nomor 1, Juni 2013/1434), hlm. 67-68. 
nilai keagamaan, sampai sekarang para pengamat Islam masih belum mendapatkan kesepakatan tentang istilah tersebut. Namun indikasi yang muncul adalah adanya kesamaan pola pemikiran pada kelompok Islam yang cenderung ekstrim yaitu pemahaman tunggal akan bentuk negara dan bentuk sistem kepemimpinan yang diidamkan.

Pada dasarnya masyarakat, semua menolak ekstremisme yang menyebabkan kekerasan sebab semua ajaran agama menurut mereka tidak mendukung kekerasan. Namun demikian, Islam sering dijadikan ilustrasi sebagai agama pendukung ekstremisme kekerasan karena dalam agama ini dikenal doktrin jihad. Jihad bagi "mereka" tidak bisa dikatakan sebagai kekerasan, karena jihad adalah perang. Kalangan teroris berargumen bahwa Islam memang menyediakan dasar yang kuat untuk berperang (jihad) asalkan untuk kepentingan agama termasuk memerangi system rezim yang tidak cocok dengan aspirasi politik Islam mereka.

Dalam pandangan mereka, Islam adalah sistem agama yang lengkap dan karenanya Indonesia harus diperintah berdasar Islam. Sistem politik Indonesia sekarang dianggap sebagai thogut, karenanya harus diganti dengan sistem Islam. Kalangan teroris menjadi isu ini sebagai ideologi yang harus mereka perjuangkan. Karena agama dianggap sebagai ideologi, maka mereka mengusulkan bahwa agama menjadi salah satu cara penyelesaiannya. Akan tetapi hal yang menarik adalah mereka tidak begitu setuju dengan cara pemerintah dengan proyek deradikalisasi yang ditujukan kepada mereka. ${ }^{9}$

Adapun istilah yang paling umum untuk memberikan label terhadap paham gerakan Islam tersebut adalah fundamentalisme (Taher 1998, 6). Oliver Roy menyebut gerakan Islam yang berorientasi pada pemberlakuan syariat sebagai Islam Fundamentalis, yang ditunjukkan dengan gerakan Ikhwanul Muslimin. Hizbuttahrir, Jamaah Islamiyah, dan Front Islamic Salvation (FIS).

\section{Ciri-Ciri Radikalisme Islam}

Jihad oleh tokoh-tokoh ekstrimis didefinisikan sebagai misi suci menegakkan ajaran agama serta cara pintas masuk surga dengan melakukan aksi bom bunuh diri serta penerangan secara membabi buta kepada target yang diyakini sebagai orang kafir atau thaghut. Skenario doktrin jihad ini menjadi semakin efektif dengan cara memboncengi isu-isu ketidakadilan, kesenjangan ekonomi, penistaan agama, dan pelanggaran HAM. Kondisi seperti ini dapat dikatakan bahwa pada hakikatnya para ekstrimis telah merobohkan

\footnotetext{
${ }^{9}$ Syafiq Hasyim, Penanggulangan Radikalisme dan Ekstremisme Berbasis Agama
} 
bangunan ajaran Islam yang Rahmatan Lil 'Alamin, yaitu Islam yang penuh kesantunan, Islam dengan ajaran damainya adalah rahmat bagi alam semesta. Ekstrimisme telah mengakibatkan persepsi yang salah terhadap umat Islam, seolah-olah Islam sebagai penebar teror, kebencian dan permusuhan yang menakutkan. Bahkan di beberapa Negara terjangkit wabah Islamphobia. Padahal kebrutalan tersebut hanya dilakukan oleh segelintir kelompok dari orang-orang yang pada prinsipnya telah berseberangan dan jauh menyimpang dari ajaran Islam itu sendiri. ${ }^{10}$

Rubaidi menguraikan lima ciri gerakan radikalisme Islam. Pertama, menjadikan Islam sebagai ideologi final dalam mengatur kehidupan individual dan juga politik ketatanegaraan. Kedua, nilai-nilai Islam yang dianut mengadopsi sumbernya di Timur Tengah secara apa adanya tanpa mempertimbangkan perkembangan sosial dan politik ketika Alquran dan Hadist hadir di muka bumi ini, dengan realitas lokal kekinian. Ketiga, karena perhatian lebih terfokus pada teks Alquran dan Hadist, maka mereka ini sangat berhati-hati untuk menerima segala budaya non-asal Islam (budaya Timur Tengah) termasuk berhati-hati menerima tradisi lokal karena khawatir mencampuri Islam dengan bidah. Keempat, menolak ideologi non Timur Tengah termasuk ideologi Barat, seperti demokrasi, sekularisme dan liberalisasi. Sekali lagi, segala peraturan yang ditetapkan harus merujuk pada Alquran dan Hadis. Kelima, gerakan kelompok ini sering berseberangan dengan masyarakat luas termasuk pemerintah. Karena itu, terkadang terjadi gesekan ideologis bahkan fisik dengan kelompok lain, termasuk pemerintah (Rubaidi 2010, 63).

Secara sederhana radikalisme adalah pemikiran atau sikap yang ditandai oleh empat hal yang sekaligus menjadi karakteristiknya, yaitu: pertama, sikap tidak toleran dan tidak mau menghargai pendapat atau keyakinan orang lain. Kedua, sikap fanatik, yaitu selalu merasa benar sendiri dan menganggap orang lain salah. Ketiga, sikap eksklusif, yaitu membedakan diri dari kebiasaan orang kebanyakan. Keempat, sikap revolusioner, yaitu cenderung menggunakan kekerasan untuk mencapai tujuan. ${ }^{11}$

\footnotetext{
${ }^{10}$ Radikalisme agama tidak hanya dikenal dalam sejarah dan dunia Islam, tetapi juga terdapat pada agama lain selain Islam. Kelompok radikal Sikh di kalangan umat Hindu misalnya, mereka menyatakan perang terhadap pemerintah India sehingga salah seorang anggotanya yang bernamaLal Singh dituduh sebagai pelaku peledakan jet Air India yang menewaskan seluruh penumpangnya(329 orang) dari penerbangan dari Toronto ke London. Dari kalangan Kristen, Rev. Paul Hillmenembak mati Dr. John Britton dan pengawal pribadinya di klinik aborsi di Pensacola Floridadengan dalih bahwa ajaran Bible membolehkan membunuhnya karena telah melakukan praktikaborsi dengan membunuh calon-calon bayi. Pembunuhan tersebut disambut dengan gembiraoleh para pengikut Kristen militan yang Pro Life. Lihat Kasjim Salenda, Terorisme..., hlm. 98.

${ }^{11}$ Agilasshofie,RadikalismeGerakanIslam,http://agilasshofie.blogspot.com/2011/10/radikalism e-gerakan politik.html, diakses pada 15 November 2017

108 | IQ (Ilmu Al-qur'an): Jurnal Pendidikan Islam | Volume 2 No. 012019
} 
Adapun faktor penyebab terjadinya Islam radikal dapat diuraikansebagai berikut: Pertama, faktor agama, yaitu sebagai bentuk purifikasi ajaran Islam dan pengaplikasian khilafah Islamiyah di muka bumi. Terdorongnya semangat Islamisasi secara global ini tercetus sebagai solusi utama untuk memperbaiki berbagai permasalahan yang oleh golongan radikal dipandang sebagai akibat semakin menjauhnya manusia dariagama.

Kedua, faktor sosial-politik. Di sini terlihat jelas bahwa umat Islam tidak diuntungkan oleh peradaban global sehingga menimbulkan perlawanan terhadap kekuatan yang mendominasi. Penyimpangan dan ketimpangan sosial yang merugikan komunitas muslim, menyebabkan terjadinya gerakan radikalisme yang ditopang oleh sentimen dan emosi keagamaan.

Ketiga, faktor pendidikan. Minimnya jenjang pendidikan, mengakibatkan minimnya informasi pengetahuan yang didapat, ditambah dengan kurangnya dasar keagamaan mengakibatkan seseorang mudah menerima informasi keagamaan dari orang yang dianggap tinggi keilmuannya tanpa dicerna terlebih dahulu, hal ini akan menjadi bumerang jika informasi didapat dari orang yang salah.

Keempat, faktor kultural. Barat dianggap oleh kalangan muslim telah dengan sengaja melakukan proses marjinalisasi seluruh sendi-sendi kehidupan muslim sehingga umat Islam menjadi terbelakang dan tertindas. Barat, dengan sekularismenya, sudah dianggap sebagai bangsa yang mengotori budaya-budaya bangsa timur dan Islam, juga dianggap bahaya terbesar keberlangsungan moralitas Islam.

Kelima, faktor ideologis anti westernisasi. Westernisasi merupakan suatu pemikiran yang membahayakan muslim dalam mengaplikasikan syari'at Islam sehingga simbol-simbol Barat harus dihancurkan demi penegakan syari'at Islam. Walaupun motivasi dan gerakan anti Barat tidak bisa disalahkan dengan alasan keyakinan keagamaan tetapi jalan kekerasan yang ditempuh kaum radikalisme justru menunjukkan ketidakmampuan mereka dalam memposisikan diri sebagai pesaing dalam budaya dan peradaban. ${ }^{12}$

Penyebaran Radikalisme Islam Melalui Lembaga Pendidikan

Kepala Badan Nasional Penanggulangan Terorisme (BNPT) Suhardi Alius pernah menegaskan bahwa saat ini tidak ada lini yang benar-benar steril dari radikalisme, termasuk dunia pendidikan. Pernyataan ini menarik disikapi secara kritis dengan mencermati dua hal. Pertama, dunia pendidikan, baik yang umum dan berbasis agama, memiliki potensi disusupi paham radikal dan teror. Sebagai contoh, pondok pesantren sebagai lembaga pendidikan

${ }^{12}$ Emna Laisa, Islam dan Radikalisme (Islamuna Volume 1 Nomor 1 Juni 2014), hlm.6-7 
agama Islam tertua di Indonesia berulang kali dikaitkan dengan isu radikalisme dan terorisme. Padahal, pondok pesantren yang jumlahnya mencapai 28.000 di nusantara, sama sekali tidak mengajarkan Islam radikal dan Islam teror, melainkan pendidikan Islam yang rahmatan lil alamin.

Kedua, mengokohkan peran institusi pendidikan Islam pondok pesantren sebagai benteng menanggulangi radikalisme dan terorisme di Indonesia. Sebab, dengan pengajaran agama Islam di pondok pesantren tersebut dapat menghapus fenomena radikalisme maupun terorisme atas nama agama. Kedua fenomena tersebut menjadikan peran strategis pondok pesantren dalam menahan laju perkembangan bibit-bibit "pemikiran keras"membumi dalam ruang pendidikan di tanah air. ${ }^{13}$

Sasaran empuk para teroris adalah anak-anak muda yang sedang berusaha mencari jati diri. Sarana yang efektif digunakan oleh kelompok radikal adalah ruang digital yang kini digemari oleh anak-anak muda masa kini, seperti media sosial, yang pada kadar tertentu sulit untuk menemukan batas kepantasan. Pemuda dituntut untuk memiliki kepekaan dan kemampuan kritis serta kemampuan untuk mengidentifikasi, melawan, mempertahankan diri dari pengaruh paham-paham radikal. Hal tersebut dapat dilakukan dengan memperluas pemahaman tentang nila-nilai kebangsaan, pancasila, dan kearifan lokal. ${ }^{14}$

Menurut survey Kementrian Komunikasi dan Informatika serta UNICEF Indonesia pada 2014, kurang lebih 43,5 juta anak dan remaja usia 10-19 tahun di Indonesia adalah pengguna internet. Artinya dunia digital sudah menjadi kebutuhan yang tak terelakan. Pada titik ini kebenaran tampak kabur ditengah riuhnya wacana yang terus dilempar keruang publik bak buih ditengah hamparan samudera yang luas.

Anak muda yang menjadi sasaran adalah anak-anak SMP dan SMA yang sedang tahap pembentukan kepribadian. Paham keagamaan mereka diberikan disekolah dengan waktu yang sangat sedikit, satu jam dalam seminggu. Konsekwensinya, jika tidak mendapatkan pelajaran dari orang tua di rumah atau ustad di lingkungan mereka, tidak tertutup kemungkinan anak-anak ini mencari pemahaman agama secara liar. Perkara pendidikan agama disekolah tidak sebatas kurikulum dengan waktu yang sangat terbatas untuk pengajaran agama tapi juga buku teks pendidikan agama yang dikeluarkan pemerintah dalam hal ini Kementerian Pendidikan dan Kebudayaan. Buku teks keagamaan menjadi

\footnotetext{
${ }^{13}$ KunWazis, Isu Radikalisme-Terorisme danPendidikan Ponpes REPUBLIKA.CO.ID, Sabtu , 17 June 2017,

${ }^{14}$ Ceramah Umum Kepala BNPT di LAN 4 Oktober 2019 110 | IQ (Ilmu Al-qur'an): Jurnal Pendidikan Islam | Volume 2 No. 012019
} 
sorotan masyarakat setelah beredarnya buku ajar yang berisi muatan intoleransi dan kekerasan di Jombang, Jawa Timur tahun lalu. ${ }^{15}$

Agama harus jadi instrumen kohesi sosial yang bisa jadikan kita semua toleran. Karena dalam agama kalau kita pelajari agama secara benar dan mendalam justru membentuk jiwa yang toleran damai. itu karakter pendidikan islam yang harus ditekankan di indonesia, sebagaimana dikatakan oleh Kamaruddin dalam konkow pendidikan, diskusi ahlidan tukar pendapat di Gedung Kementerian Pendidikan, Jakarta, Rabu (4/11/2015). Kamaruddin menuturkan, meskipun Islam di Indonesia menuai pujian dari banyaknegara karena mampu menunjukkan sikap yang moderat dan toleran, bukti-bukti menunjukkan bahwa islam dalam bentuk yang lebih tidak toleran dan ekstrimis juga ada di negara ini. kecenderungan sikap ekstrimis kurang ditemukan di lembaga-lembaga pendidikan Islam, melainkan justru di lembaga pendidikan umum baik swasta maupun negeri. Berdasarkan penelitian, kata Kamaruddin, hanya 30\% sekolah yang terpengaruh radikalisme yang dampaknya dapat meluas jika tidak segera diantisipasi. Jalur utama masuknya radikalisme di sekolah adalah organisasi masyarakat Islam radikal yang semakin meningkat dalam hal jumlah dan aktivitas. ${ }^{16}$

Berdasarkan penelitian yang dilakukan oleh Arif Mulyadi Secara garis besar penanaman radikalisme Islam melalui beberapa kegiatan yang dilakukan di dalam sekolah maupun di luar sekolah diantaranya yaitu: Mentoring, Dari kegiatan mentoring yang merupakan salah satu program rohis dapat dianalisis bahwasanya kegiatan mentoring merupakan langkah awal yang digunakan oleh sebagian kaum muslimin yang menginginkan tegaknya Khilafah Islam di Indonesia (Ghoffar 2016). Liqa, mengadakan pertemuan berkala untuk penguatan visi misi serta perencanaan strategi dan penguatan jaringan. Kajian-Kajian sebagai sarana doktrin dan brainwash.

\section{Nilai Luhur Pendidikan Agama Islam Anti Radikalisme}

Implementasi pendidikan anti terorisme melalui pembelajaran PAI bertujuan untuk mewujudkan masyarakat muslim yang toleran dan cinta damai di tengah kehidupan bangsa Indonesia yang plural. Sebagaimana kita ketahui, bangsa Indonesia hidup bersama dalam keragaman suku, agama, ras, dan adat kebiasaan. Akhir-akhir ini tak jarang keragaman tersebut, termasuk keragaman dalam hal agama ditunggangi oleh oknum-oknum tertentu untuk melakukan aksi terorisme. Alhasil agama yang diyakini oleh masyarakat Indonesia

${ }^{15}$ Abdallah, Opini harian Koran Tempo, edisi, 13 September 2016.

${ }^{16}$ http:// kabar24.bisnis.com/read/20151104/255/488782/pendidikan-agama-islam-disekolah-cegah-paham-radikalisme. Diakses pada 15 November 2017 
mengalami distorsi, termasuk agama Islam. Akibat aksi terorisme tersebut, Islam sebagai agama yang mengajarkan praktik toleransi kepada pemeluknya berubah menjadi agama yang seakan "garang" di mata pemeluk agama yang lain. Di sinilah, implementasi pendidikan anti terorisme melalui pembelajaran PAI diharapkan dapat menciptakan masyarakat muslim yang toleran dan cinta damai baik terhadap sesama pemeluk agama Islam maupun pemeluk agama lainnya. ${ }^{17}$

Pendidikan Islam yang berada dipunggung guru bagai pedang bermata dua, di satu sisi bisa menangkal radikalisme, di sisi yang lain justru bisa melahirkan radikalisme agama. Pendidikan agama yang salah bisa menjadikan seseorang menjadi radikal. Di beberapa sekolah, siswa bukannya diperkenalkan dengan ajaran Islam yang penuh cinta, namun justru dikenalkan dengan ajaran yang keras, agresor, dan pembalas dendam. Oleh sebab iti pendidikan harus bisa berperan sebagai sarana membangun ketahanan individu dari masuknya nilai-nilai yang menyimpang dari kearifan lokal jati diri bangsa.

Kurikulum pendidikan agama yang lebih berorientasi pada hukum (nomos oriented religion) yang kaku dan eksklusif, bukannya pada cinta (eros oriented religion) yang moderat dan inklusif. Padahal Islam adalah ajaran yang sangat berorientasi pada ajaran cinta (eros). Dalam Al-Qur'an, ada lima kali lebih banyak asma Jamaliyyah ketimbang Jalaliyyah. Allah Swt sendiri lebih banyak menampilkan diri-Nya dalam wajah yang lembut dan penuh cinta. Tapi kenapa pengajar agama kita lebih suka menampilkan wajah keras dalam Islam? Mengapa seolah Nabi itu hanya mengajarkan perang dan kekerasan? Seolah belum dikatakan beriman seseorang kalau belum mengkafirkan orang dan menggorok leher orang? Kenapa seolah-olah kemuliaan mati syahid itu harus di medan perang? Nabi tidak syahid di medan perang. Tapi siapa yang berani bilang Nabi tidak mulia? Bukankah Nabi justru mengingatkan ada jihad yang lebih besar, yaitu jihad melawan hawa nafsu?

Untuk mencegah lahirnya radikalisme ini, perlunya merombak total carapandang terhadap agama Islam. Di sinilah peran guru sebagai pendidik menduduki posisi kunci. Karena di tangan merekalah, anak didik bisa dibentuk cara pandangnya pada agama dengan kacamata cinta. Ajarkan pada anak kecil nama Jamaliyyah bukan Jalaliyyah. Pendidikan agama Islam harus moderat, ini agama cinta kasih. Jadilah figur pendidik yang modal utamanya adalah kasih sayang kepada siswa. Ajarkan bahwa Islam itu adalah kasih sayang Allah Swt sebagai ramatan lil 'alamin. Moderat dalam Islam jangan disalah artikan sebagai

17 Novan Ardy Wiyani, Pendidikan Agama Islam Berbasis Anti Terorisme Di SMA,(Jurnal Pendidikan Islam :Volume II, Nomor 1, Juni 2013/1434), hlm. 67-68. 
golongan yang tidak memiliki pendirian, namun moderat dalam artian mengambil jalan tengah yang mengedepankan aspek mashlahah al-mursalah sebagai konsekuensi atas fakta bahwa masyarakat Indonesia dilahirkan dengan beragam ras, suku, bahasa, adat, warna kulit serta keyakinan akan tuhan yang beragam.

Prof. DR. Syamsul Maarif, M.Ag menyampaikan bahwa paradigma pendidikan harus menjadi wahana yang dapat mentransmisikan budaya serta kearifan lokal sebagai usaha mempertahankan persatuan kesatuan bangsa. Oleh karena itu menurutnya perlu adanya rekonstruksi pendidikan yang bersifat lebih universal sehingga mampu menjadi solusi bagi masalah multidimensional seperti radikalisme. ${ }^{18}$ Dalam Pendidikan agama Islam di sekolah pengajaran akan sejarah agama-agama yang ada di Indonesia menjadi urgen untuk diajarkan agar peserta didik memahami bagaimana transformasi kehidupan umat beragama yang terjadi di masyarakat Indonesia.

Dalam Islam, ajaran tentang toleransi bisa diaplikasikan lewat beberapa cara, di antaranya: Pertama, berpegang pada prinsip kalimatun sawa (commomplatform) untuk pergaulan antar umat beragama dan berbagai kepentingan masyarakat yang plural. Titik persamaan ini terletak pada kebutuhan untuk mencintai tuhan, mencintai makhluk tuhan, dan mengakui suarahati nurani. Memberikan penguatan kepada peserta didik bahwa dijadikannya keyakinan yang berbeda pada manusia merupakan kehendak dari Allah SWT. Kedua, menumbuhkan pemahaman keagamaan yang integratif, egaliter, inklusif, dan plural dengan melakukan penguatan metodologi terhadap kajian-kajian Islam, semisal pengembangan metode takwil (hermeneutik), serta pentingnya mendefinisikan ulang tentang diri dan orang lain. dalam hal ini bisa melalui pemberan materi mengenai antropologi agama, sosiologi dan lain sebagainya yang berkaitan dengan konstruksi kehidupan sosial kemasyarakatan dengan segala aspek yang membangunnya. Termasuk mengkaji konsep-konsep yang selama ini dianggap telahbaku, seperti konsep mukmin/kafir, muslim/munafik dan lain-lain. Ketiga, mentradisikan musyawarah dan berdiskusi. Tradisi musyawarah ini akan menumbuhkan sikap toleran dan mengakui keberagaman pemikiran dan sikap setiap insan dalam mencari hal yang baik dan benar. Kebaikan dan kebenaran bisa datang dari manapun, termasuk dari orang yang dibenci sekalipun. Untuk itu, pemahaman keagamaan harus di-bangun secara inklusif dan tidak mengedepankan klaim. Klaim kebenaran dari suatu kelompok dengan menafikan kebenaran dari kelompok lainhanya akan menimbulkan kecurigaan dan pertentangan. Keempat, jaminan terhadap terpenuhinya lima hak dasar manusia,yakni: (1) hifdz al-diin,

${ }^{18}$ Sidang Pengukuhan guru besar UIN Walisongo 4 Juli 2019 
menjamin keyakinan agama masing-masing; (2)hifdz al-nafs, jaminan terhadap keselamatan jiwa setiap warga masya-rakat; (3) hifdz al-aql, menjamin setiap bentuk kreasi pikiran, baik bersifat intelektual maupun budaya dan seni; (4) hifdz al-nasl, menjamin kese-lamatan keturunan dan keluarga dengan menampilkan moral yang kuat;dan (5) hifdz al-mal, menjamin keselamatan harta benda dan hak kepemilikan. ${ }^{19}$

Konsep dasar tersebut secara dini harus ditanamkan pada setiap muslim lewat pendidikan sekolah maupun pendidikan di luar sekolah. Terkait dengan pendidikan agama, setiap pendidik harus mengajarkan agama secara integral-komprehensif dengan melihat kebenaran dari berbagai perspektif walaupun tetap harus meyakini kebenaran agama yang dianutnya. ${ }^{20} \mathrm{Hal}$ ini dilakukan agar peserta didik mampu memetakan mana wilayah yang berkaitan dengan ranah pribadinya sebagai pemeluk agama dan mana wilayah yang berkaiatan dengan hubungan hidup dengan masyarakat yang tidak satu keyakinan dengannya.

Beragam upaya untuk mencegah meluasnya paham atau pemikiran radikal telah dilakukan oleh pemerintah bekerjasama dengan ulama-ulama. Para ulama bersinergi pula dengan aparat untuk dapat menyampaikan pesan akan religiusitas yang menjunjung tinggi nasionalisme. Sampai muncul pula arahan dari Menteri Agama Republik Indonesia untuk memantau dan mengawasi penyebaran paham atau pemikiran radikal terutama di perguruan tinggi. Kenapa di perguruantinggi? Seperti yang telah disebutkan di atas bahwa salah satu jalan penyebaran paham radikal adalah melalui institusi/lembaga pendidikan khususnya perguruan tinggi.

Arahan yang ditujukan kepada rektor dan ketua perguruan tinggi, terutama perguruan tinggi di bawah naungan Kementerian Agama ini adalah mengenai pengawasan terhadap semua aktifitas civitas akademika agar tidak terpengaruh atau justru menyebarkan paham radikal. Termasuk di dalam arahan tersebut adalah pada saat pelaksanaan rekruitmen dosen serta tenaga kependidikan lainnya agar diseleksi dengan ketat terkait paham dan komitmennya terhadap nilai-nilai keislaman dan kebangsaan. Pengawasan terhadap aktivitas dosen yang terlibat dalam jaringan ekstrimisme dan radikalisme mamang masih belum dapat dilaksanakan dengan maksimal. Tentu ini menjadi pekerjaan tersendri bagi pemangku kebijakan untuk bisa menyelesaikan mslah tersebut.

\footnotetext{
${ }^{19}$ Buddy Munawar Rahman, Kontekstualisasi Doktrin Islam dalam Sejarah (Jakarta:Paramadina, 1994), 546-549.

${ }^{20}$ Emna Laisa, Islam dan Radikalisme (Islamuna Volume 1 Nomor 1 Juni 2014), hlm.15
} 
Radikalisme lebih banyak disebabkan oleh adanya faham atau pemikiran yang sempit terhadap suatu fenomena. Oleh sebab itu jika radikalisme ingin dieliminir bahkan dihilangkan harus diawali dari pembinaan atau bimbingan cara pandang atau cara fikir terhadap suatu fenomena. Nur Syam (2009) dalam buku Tantangan Multikulturalisme Indonesia memiliki analisis yang cukup menarik bahwa untuk melahirkan cara pandang yang tepat perlu belajar dari ideologi ahlussumahwal jamaah atau NU yang dicirikan dengan empat hal;

Pertama, tawasuth (moderat) mengambil jalan tengah yang lebih bijaksana. Doktrin ini mengajarkan bahwa manusia memiliki kebebasan untuk melaksanakan suatu aktivitas tetapi sebebas apapun manusia masih dibatasi oleh kehendak Tuhan Yang Maha Kuasa. Artinya dalam menjalankan tugasnya di muka bumi sebagai penegak agama Allah tidak lantas menjadikan manusia lupa bahwa kehendak untuk menjadikan manusia beragam adalah mutlak kehendak Allah. Jika ingin meraih kesuksesan, manusia wajib ikhtiyar secara optimal tetapi jangan lupa bahwa Allah swt juga ikut menentukan keberhasilan. Setelah berusaha manusia wajib berdoa dan pasrah kepada Allah swt. Semangat yang terlalu tinggi tanpa kendali akan menjadikan manusia terjerumus pada perbuatan israf (berlebihan). Jika demikian maka Radikalisme dan ektrimisme cenderung pada sikap israf.

Kedua, tawazun (keseimbangan). Doktrin ini mengajarkan bahwa manusia dalam memandang suatu realitas tidak boleh bersifat ektrem baik kekiri atupun ke kanan. Artinya manusia yang baik tidak terlalu berlebihan pada saat senang atau benci kepada sesuatu. Hal ini didasarkan asumsi bahwa sebaik baik menurut pandangan manusia belum tentu baik menurut Allah swt, sebaliknya sejelek jelek dalam pandangan manusia juga belum tentu jelek menurut Allah swt.

Ketiga, i'tidal (keadilan). Doktrin ini mengajarkan bahwa diantara sesama manusia harus saling memebrikan kepercayaan dan kepercayaan yang dibangun harus memberikan peran secara proporsional. Dunia akan cepat hancur jika masing masing-masing elemen tidak memiliki kesadaran untuk melaksanakan peran masing-masing secara proporsional.

Keempat, tatharruf (universsalisme). Doktrin ini mengajarkan setiap manusia agar lebih mengedepankan pemahaman Islam yang bersifat universal (global). Kebenaran Islam dilihat dari norma-norma yang bersifat umum seperti keadilan, kemanusiaan, keselamatan dan kesejahteraan.

Secara garis besar dari nilai-nilai yang telah dipaparkan di atas berpusat pada penguatan keshalehan vertikal (Hablumminallah), dan keshalehan horizontal (hablumminannas). 
Muhammad Naelul Mubarok

\section{Daftar Pustaka}

Abdallah, Opini harian Koran Tempo, edisi, 13 September 2016.

Buddy Munawar Rahman, Kontekstualisasi Doktrin Islam dalam Sejarah (Jakarta:Paramadina, 1994), 546-549.

Hasyim Syafiq, Penanggulangan Radikalisme dan Ekstremisme Berbasis Agama

Kun Wazis, Isu Radikalisme-Terorisme danPendidikan Ponpes REPUBLIKA.CO.ID, Sabtu , 17 June 2017

Laisa Emna, Islam dan Radikalisme (Islamuna Volume 1 Nomor 1 Juni 2014), hlm.2.

Mulyadi Arif,Peran guru agama Islam dalam Menanggulangi Paham Radikalisme, (Safira Vol 2/No.1/2017) hal.50

Nadia Zunly, Akar-akar Radikalisme Islam dalam Tafsir Fi Zilal al-Qur'an Karya Sayyid Quth,Mukaddimah, 18 (2), 2012: 301-323

Roqib. Moh, Filsafat Islam, 179.

Purwanto M. Ngalim, Ilmu Pendidikan Teoritis dan Praktis (Bandung: Remaja Rosdakarya,1995), hlm. 15.

Wiyani, Novan Ardy, Pendidikan Agama Islam Berbasis Anti Terorisme Di SMA, (Jurnal Pendidikan Islam :Volume II, Nomor 1, Juni 2013/1434), hlm. 67-68.

Agilasshofie,RadikalismeGerakanIslam,http://agilasshofie.blogspot.com/2011/10/radi

kalisme-gerakan politik.html, diakses pada 15 November 2017

http://kabar24.bisnis.com/read/20151104/255/488782/pendidikan-agama-islam-

di-sekolah-cegah-paham-radikalisme. Diakses pada 15 November 2017

http://www.ahlulbaitindonesia.or.id/berita/peran-kunci-pendidikan-dalam-menangkalradikalisme-agama/, diakses pada 15 Nov 2017. 